\title{
STRUCTURE AND POPULATION DYNAMICS OF ASCLEPIAS SYRIACA L. IN THE AGRICULTURAL LAND
}

\author{
ŽANETA PAUKOVÁ*, VIKTÓRIA KÁDEROVÁ, LADISLAV BAKAY \\ Slovak University of Agriculture in Nitra
}

PAUKOVÁ, Ž. - KÁDEROVÁ, V. - BAKAY, L.: Structure and population dynamics of Asclepias syriaca L. in the agricultural land. Agriculture (Pol'nohospodárstvo), vol. 59, 2013, no. 4, pp. 161-166.

This paper evaluates the selected population-biological characteristics and size structure of invasive neophyte Asclepias syriaca in three habitat types (abandoned vineyards, grassland and road side) in the district of Vel'ký Krtís in Central Slovakia. Three permanent research plots $(1 \mathrm{~m} \times 1 \mathrm{~m})$ were established and monitored during the growing season in 2012. The density of the population at the end of the growing season ranged from 15 to 29 stems per $\mathrm{m}^{2}$. The greatest average plant height was recorded in the roadside plot $(129 \mathrm{~cm})$ and the lowest in the abandoned vineyard $(92 \mathrm{~cm})$. Main stem thickness reached $1.5-2.0 \mathrm{~cm}$ at the base. The highest number of main stem leaves was recorded at the end of June and July (from 24 to 27). The number of inflorescences varied from 1.6 to 3.4 and the number of fruits ranged from 1.2 to 3.8 per generative stem. Statistically significant differences were found in the plant height, thickness of the main stem and the number of fruits at the three different locations.

Key words: Asclepias syriaca, population-biological properties, size structure, agricultural land

The expansion of potential invasive plant or expansive plant species from urban areas into abandoned vineyards, neglected fields, degraded habitats and other areas in agricultural land is possible and can threaten biodiversity and their removal can cause expense to farmers and land owners. Such species include Common Milkweed (Asclepias syriaca L.). Common Milkweed (Asclepias syriaca L., Asclepiadaceae) is a dicotyledonous perennial weed, native to Canada, north, central north-eastern and south-eastern United States (Bhowmik \& Bandeen 1976; Cramer \& Burnside 1982). The species is characterised by erect stems with large leathery leaves and well-marked pink flowers. It blooms from June to July. Fruits are oblong-ovate shaped pods with a white pericarp. Seeds with plumes of white shiny hairs ripen in August and September. Asclepias syriaca reproduces by seed and by adventitious buds on its roots (Bhowmik \& Bandeen
1976; Valachovič 1989, 1991). The species was introduced to Europe from the eastern part of Northern America as an ornamental plant in the $19^{\text {th }}$ century (Bhowmik \& Bandeen 1976; Cramer \& Burnside 1982). Medvecká et al. (2012) state that the first occurrence of this taxon in Slovakia was in 1917. Due to its spread in Slovakia, it is considered as a potential invasive neophyte (Gojdičová et al. 2002; Medvecká et al. 2012). The most common habitats are hot and dry sites in southern Slovakia, namely habitats along railways, ditches, fields adjacent to roads and in agroecosystems. The species can cause yield losses to farmers. Many authors have previously studied the biology and distribution of this species in the world (Bhowmik 1978; Bhowmik \& Bandeen 1976; Cramer \& Burnside 1982; Campbell 1984; Hartzler \& Buhler 2000; Csontos et al. 2009 and others); as well as in Slovakia Ružička (1952), Valachovič (1987, 1988, 1989, 1991), Medvecká et

Ing. Žaneta Pauková, PhD. (*Corresponding author), Slovak University of Agriculture in Nitra, Department of Ecology, Faculty of European Studies and Regional Development, Mariánska 10, 94976 Nitra, Slovak Republic. E-mail: zaneta. paukova@uniag.sk 
al. (2012) and others. This paper presents the results of the evaluation of selected population-biological characteristics and size structure of potentially invasive neophyte $A$. syriaca, which is currently spreading in some localities of Central Slovakia. However, according to Act No. 543/2002 on Protection of Nature and Land in Slovakia and the Decree of the Ministry of the Environment No. 173/2011, Common Milkweed does not belong to the invasive plant species that need to be removed. Expansively spreading plants of Common Milkweed represent a great threat to the agricultural land, especially near cultivated land. It was demonstrated that the values of several reproductive traits of the studied populations exceeded the values reported for the native populations (Bhowmik \& Bandeen 1976). It forecasts that $A$. syriaca could become an invasive plant in Slovakia.

\section{MATERIAL AND METHODS}

Three study sites were selected in the Ipel' valley in the region of its tributaries: the Krtís and the Plachtinský, in the vicinity of villages Seleštany, Sklabiná and Nová Ves in the district Vel'ký Krtíš, Banská Bystrica County, Central Slovakia. The altitude of the villages is approximately $160 \mathrm{~m}$ above sea level. It belongs to the hot and dry climate zone. The annual rainfall is around $600 \mathrm{~mm}$. Soils are brown, illimerised, alluvial and floodplain (Michal 2003). Climadiagrams that present the average air

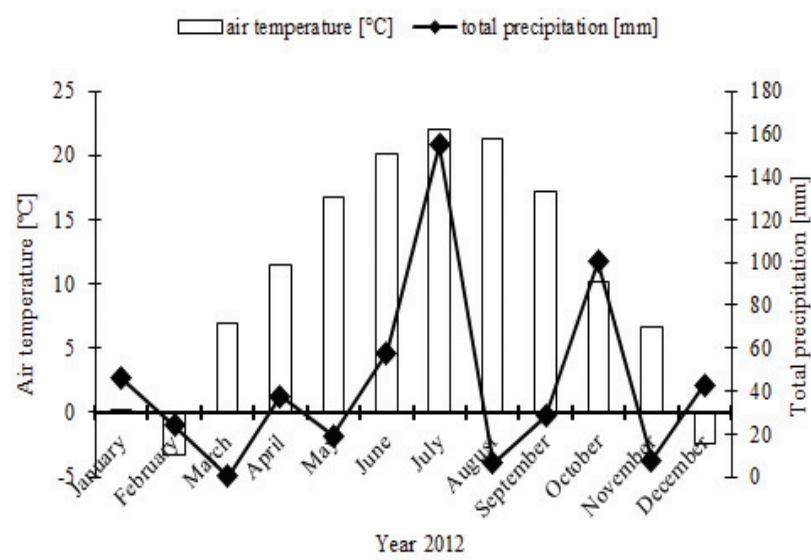

Figure 1. Climadiagrams for the year 2012 at the research site in the district of Vel'ký Krtís (SHMÚ 2013, processed by the authors) temperature $\left({ }^{\circ} \mathrm{C}\right)$ and total monthly precipitation $(\mathrm{mm})$ in the village of Dolné Plachtince in the observed district are shown in Figure 1.

Selected populations of $A$. syriaca were studied in three different habitats: an abandoned vineyard (A) in the village of Seleštany, grassland (B) in the village of Sklabiná and along the roadside (C) in the village of Nová Ves. The observations were done in three non-destructive plots $(1 \mathrm{~m} \times 1 \mathrm{~m})$ in each habitat by the random plot selection method. The investigated plots were located in the interior of the stands to avoid edge effect. Population density (stem per $\mathrm{m}^{2}$ ) was determined by the method of repeated census of stem (ramet). The height of the main stem $(\mathrm{cm})$ was measured from the soil surface to the apical part of the stem by folding rule. The thickness of the main stem in the base $(\mathrm{cm})$ was measured by calliper (16FN Mahr). The number of leaves of the main stem, the number of inflorescences and the number of fruit per generative stem were monitored using the repeated census method. After obtaining the variables, the following parameters were calculated: the average density of populations, the average height of plants, the average thickness of the stem base, the average number of the main stem leaves, the percentage of generative stems, the percentage of stems with fruits, the average number of inflorescences and fruits per stem and per generative stem (Table 4). The size structure was evaluated on the basis of size classes with the same range of values. The nomenclature of accompanying species was adjusted according to Marhold et al. (1998). Field measurements were carried out at regular monthly intervals from April to September during the growing season in 2012 (29 April, 26 May, 28 June, 30 July, 31 August and 29 September). The comparison of the means of population-biological characteristics and size structures among the three study sites was done by statistical analysis ANOVA in Statgraphics Centurion by Kruskal-Wallis Test and LSD test. Significant differences were accepted at $P<0.05$.

\section{RESULTS AND DISCUSSION}

Site A (abandoned vineyard) was covered by Centaurium erythraea Rafn, Rubus fruticosus L., 


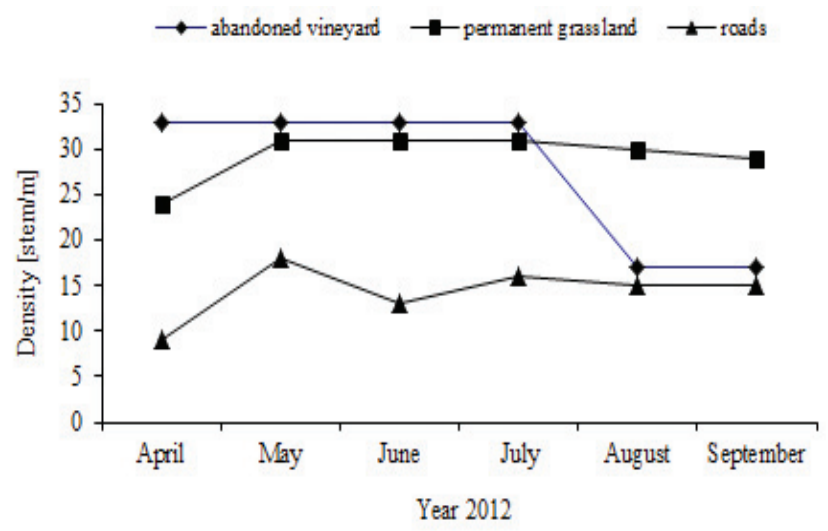

Figure 2. Dynamics of the number of stems of Asclepias syriaca in different habitats during the growing season of 2012 in Central Slovakia

Sambucus ebulus L. and Verbascum densiflorum Bertol. with vegetation coverage of $20 \%$. Here, $A$. syriaca colonised a $1260-\mathrm{m}^{2}$ area. Site B (grassland) colonised area was $4508 \mathrm{~m}^{2}$ and site C (roadside) colonised area was approximately $120 \mathrm{~m}^{2}$. The major accompanying species at sites $\mathrm{B}$ and $\mathrm{C}$ consisted of Achillea millefolium L., Centaurea jacea L., Cichorium intybus L., Cirsium arvense (L.) Scop., Convolvulus arvensis L. and Rubus fruticosus L. with a coverage of $30-40 \%$. Valachovič (1987) states that $A$. syriaca dominates in ruderal stands accompanied by Artemisia vulgaris, Galium aparine, Solidago gigantea, Stenactis annua and Urtica dioi$c a$ in West Slovakia.
The highest population density was found in the abandoned vineyard ( 33 stems per $\mathrm{m}^{2}$ ) until the end of July, then it decreased by the self-thinning process to 17 individuals in August, when the total rainfall was only $6.3 \mathrm{~mm}$. The density dynamics of the population growing along the roadside (site C) resulted with the maximum value in May (18 stems per $\mathrm{m}^{2}$; Figure 2). In comparison, Valachovič (1989) observed higher density ( 45 stems per $\mathrm{m}^{2}$ ) of the population in ruderal stands in West Slovakia. Csontos et al. (2009) indicate lower density of Common Milkweed in Hungary that varied between 7.4 (in abandoned vineyard) and 18.1 stems per $\mathrm{m}^{2}$ (in neglected field). The number of individuals of $A$. syriaca recorded by Bhowmik and Bandeen (1976) in North America was only $1.2-8.8$ stems per $\mathrm{m}^{2}$.

The assessment of the size structure of $A$. syriaca populations at the end of the growing season showed that about $79 \%$ of the plants on grassland reached heights from 102.3 to $113.3 \mathrm{~cm}$. The maximum height of plants was observed along the roadside, where $20 \%$ of the stems varied from 146.7 to $157.7 \mathrm{~cm}$ (Figure 3).

In general, we can conclude that our study confirmed statistically significant difference in the median value of the main stem height $(P=0.005)$, stem thickness $(P=0.00038)$ and the number of fruits $(P$ $=0.0000025)$ at the three different locations. The summary statistics of these characteristics are shown in Tables 1-3. The values with different letters (A,

口abandoned vineyard (A) Epermanent grassland (B) Droad (C)

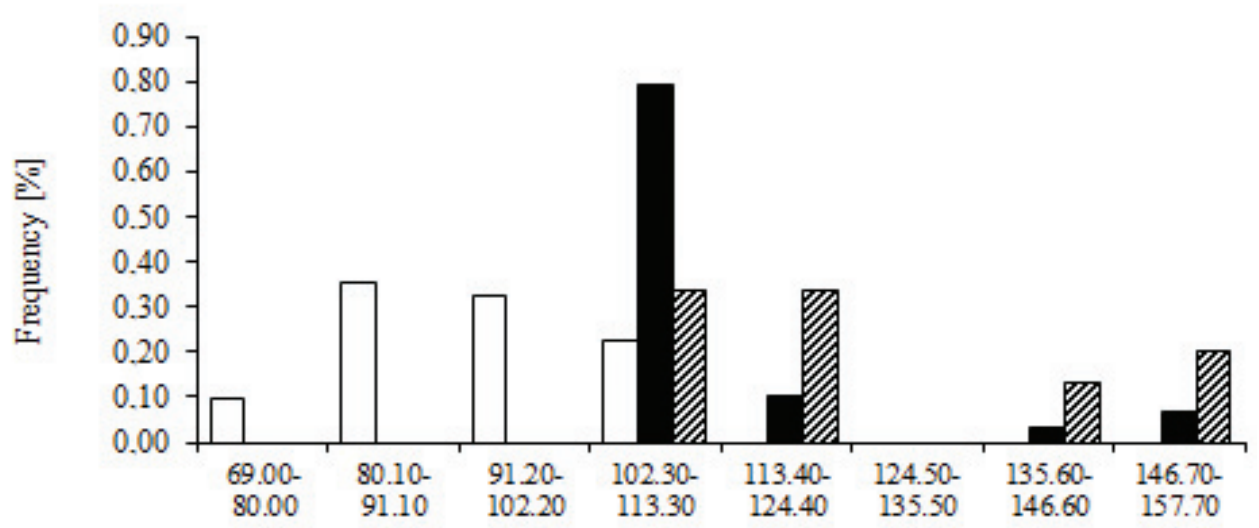

Size of classes [mm]

Figure 3. Size structure of Asclepias syriaca in different habitats at the end of September, 2012, in Central Slovakia 
B, C) in columns indicate statistically significant differences according to the Kruskal-Wallis test $(P<0.05)$. The statistically significant difference was not confirmed in the number of leaves of the main stem and the number of inflorescences at the three observed habitats.

Shannon and Wyatt (1986) discussed the life strategy of Asclepias exaltata. After seed germina- tion, the seedlings spent several years as non-flowering plants and stored photosynthetic resources in the roots. When the plants stored certain resources, they produced inflorescences but no mature fruits. These plants produced only pollen for pollination of older plants. After having accumulated enough resources, the plants produced mature fruits. In our study, the percentage of generative stems of

$\mathrm{T}$ a

Summary statistics of the main stem height of Asclepias syriaca in the district of Vel'ký Krtíš in July $2012(P<0.05)$

\begin{tabular}{|c|c|c|c|c|c|c|c|c|c|c|}
\hline $\begin{array}{l}\text { Habitats/statistic } \\
\text { characteristics }\end{array}$ & $\begin{array}{c}\text { Count } \\
{\left[\text { stems } / \mathrm{m}^{2}\right]}\end{array}$ & $\begin{array}{c}\text { Average } \\
{[\mathrm{m}]}\end{array}$ & $\begin{array}{c}\text { Median } \\
{[\mathrm{m}]}\end{array}$ & $\begin{array}{l}\text { Standard } \\
\text { deviation }\end{array}$ & $\begin{array}{l}\text { Coefficient of } \\
\text { variation }[\%]\end{array}$ & $\begin{array}{l}\text { Minimum } \\
{[\mathrm{m}]}\end{array}$ & $\begin{array}{c}\text { Maximum } \\
{[\mathrm{m}]}\end{array}$ & $\begin{array}{c}\text { Range } \\
{[\mathrm{m}]}\end{array}$ & $\begin{array}{l}\text { Standard } \\
\text { skewness }\end{array}$ & $\begin{array}{l}\text { Standard } \\
\text { kurtosis }\end{array}$ \\
\hline Vineyard & 33 & 0.92 & $0.96^{\mathrm{a}}$ & 0.13 & 14.15 & 0.46 & 1.10 & 0.64 & -3.53 & 4.12 \\
\hline Grassland & 31 & 0.94 & $0.95^{\mathrm{a}}$ & 0.09 & 10.30 & 0.69 & 1.13 & 0.44 & -0.71 & 0.14 \\
\hline Roadside & 16 & 1.08 & $1.07^{\mathrm{b}}$ & 0.16 & 14.74 & 0.84 & 1.37 & 0.53 & 0.40 & -0.53 \\
\hline Total & 80 & 0.96 & 1.01 & 0.14 & 14.28 & 0.46 & 1.37 & 0.91 & -0.32 & 4.25 \\
\hline
\end{tabular}

Values with different letters $(a, b)$ in column indicate statistically significant difference

T a b 1 e 2

Summary statistics of the main stem thickness of Asclepias syriaca in the district of Vel'ký Krtíš in July $2012(P<0.05)$

\begin{tabular}{|c|c|c|c|c|c|c|c|c|c|c|}
\hline $\begin{array}{l}\text { Habitats/statistics } \\
\text { characteristic }\end{array}$ & $\begin{array}{c}\text { Count } \\
{\left[\mathrm{stems} / \mathrm{m}^{2}\right]}\end{array}$ & $\begin{array}{c}\text { Average } \\
{[\mathrm{cm}]}\end{array}$ & $\begin{array}{c}\text { Median } \\
{[\mathrm{cm}]}\end{array}$ & $\begin{array}{l}\text { Standard } \\
\text { deviation }\end{array}$ & $\begin{array}{l}\text { Coefficient of } \\
\text { variation [\%] }\end{array}$ & $\begin{array}{l}\text { Minimum } \\
{[\mathrm{cm}]}\end{array}$ & $\begin{array}{c}\text { Maximum } \\
{[\mathrm{cm}]}\end{array}$ & $\begin{array}{c}\text { Range } \\
{[\mathrm{cm}]}\end{array}$ & $\begin{array}{l}\text { Standard } \\
\text { skewness }\end{array}$ & $\begin{array}{l}\text { Standard } \\
\text { kurtosis }\end{array}$ \\
\hline Vineyard & 33 & 1.68 & $1.70^{\mathrm{a}}$ & 0.15 & 8.95 & 1.00 & 1.80 & 0.80 & -6.99 & 14.70 \\
\hline Grassland & 31 & 1.68 & $1.70^{\mathrm{a}}$ & 0.11 & 6.70 & 1.50 & 2.00 & 0.50 & 1.78 & 0.83 \\
\hline Roadside & 16 & 1.82 & $1.80^{\mathrm{b}}$ & 0.11 & 6.16 & 1.70 & 2.00 & 0.30 & 1.18 & -0.63 \\
\hline Total & 80 & 1.71 & 1.70 & 0.14 & 8.23 & 1.00 & 2.00 & 1.00 & -4.56 & 13.49 \\
\hline
\end{tabular}

Values with different letters $(a, b)$ in column indicate statistically significant difference

T a b 1 e 3

Summary statistics of the number of fruits of Asclepias syriaca in the district of Vel'ký Krtíš in July $2012(P<0.05)$

\begin{tabular}{|c|c|c|c|c|c|c|c|c|c|c|}
\hline $\begin{array}{l}\text { Habitats/statistic } \\
\text { characteristics }\end{array}$ & $\begin{array}{c}\text { Count } \\
{\left[\mathrm{stems} / \mathrm{m}^{2}\right]}\end{array}$ & $\begin{array}{c}\text { Average } \\
\text { [piece] }\end{array}$ & $\begin{array}{l}\text { Median } \\
\text { [piece] }\end{array}$ & $\begin{array}{l}\text { Standard } \\
\text { deviation }\end{array}$ & $\begin{array}{l}\text { Coefficient of } \\
\text { variation }[\%]\end{array}$ & $\begin{array}{l}\text { Minimum } \\
\text { [piece] }\end{array}$ & $\begin{array}{l}\text { Maximum } \\
\text { [piece] }\end{array}$ & $\begin{array}{l}\text { Range } \\
\text { [piece] }\end{array}$ & $\begin{array}{l}\text { Standard } \\
\text { skewness }\end{array}$ & $\begin{array}{c}\text { Standard } \\
\text { kurtosis }\end{array}$ \\
\hline Vineyard & 33 & 1.96 & $2.00^{\mathrm{b}}$ & 1.93 & 97.89 & 0.00 & 6.00 & 6.00 & 0.63 & -1.63 \\
\hline Grassland & 31 & 0.77 & $1.00^{\mathrm{a}}$ & 0.92 & 118.89 & 0.00 & 3.00 & 3.00 & 2.34 & 0.37 \\
\hline Roadside & 16 & 4.19 & $4.50^{\mathrm{c}}$ & 1.79 & 42.91 & 0.00 & 6.00 & 6.00 & -1.94 & 0.71 \\
\hline Total & 80 & 1.95 & 2.75 & 1.99 & 102.53 & 0.00 & 6.00 & 6.00 & 2.14 & -1.85 \\
\hline
\end{tabular}

Values with different letters $(a, b, c)$ in column indicate statistically significant difference 
T a b

Population-biological characteristics of Asclepias syriaca in the villages of Selešt'any (A), Sklabiná (B) and Nová Ves (C) in Central Slovakia in 2012

\begin{tabular}{|l|c|c|c|}
\hline Habitats/population-biological characteristics & $\begin{array}{c}\text { Abandoned } \\
\text { vineyard (A) }\end{array}$ & Grassland (B) & Roadside (C) \\
\hline Density [stems/m²] in June & 33.0 & 31.0 & 13.0 \\
Percentage of reproductive stems [\%] in June & 79.4 & 46.9 & 71.4 \\
Percentage of stems with pods [\%] in July & 58.8 & 25.0 & 62.5 \\
Number of inflorescences per reproductive stem [piece] & 3.4 & 1.6 & 1.9 \\
Number of inflorescences per stem [piece] & 2.7 & 0.7 & 3.2 \\
Number of pods per reproductive stem [piece] & 2.5 & 1.2 & 2.3 \\
Number of pods per stem [piece] & 2.0 & 0.5 & 2.1 \\
Number of pods per number of inflorescences on a stem [piece] & 0.7 & 0.7 & \\
\hline
\end{tabular}

Common Milkweed varied from 46.9 to 79.4 in Central Slovakia (Table 4). Csontos et al. (2009) observed higher values for both the percentage of reproductive stems (89-98\%) and the number of inflorescences per reproductive stem (from 3.1 to 5.1) in two neglected fields and one abandoned vineyard in Hungary. Valachovič (1989) reported 0.5 pods per stem in populations growing along railways in Western Slovakia. This corresponds to our results obtained on the grassland (site B). Higher values were observed on the abandoned vineyard (site A) and on roadside (site C) (2.0 and 2.3, respectively; Table 4).

\section{CONCLUSIONS}

The assessment of the size structure and population dynamics of neophyte $A$. syriaca in Central Slovakia showed statistically significant differences in the stem height, main stem thickness and number of fruits in three different habitats: abandoned vineyard, grassland and roadside. The highest population density was reached in May and in June, after which the intraspecific competition leads to a gradual decrease in the density. Optimal flowering was in June. Maximum number of leaves was observed in June and July. Significant foliage decrease occurred at the end of the growing season. Expansively spreading plants of Common Milkweed represent a great threat to the agricultural land, especially near cultivated land. It was demonstrated that the values of several reproductive traits of the studied populations exceeded the values reported for the native populations. It forecasts that Common Milkweed could become an invasive plant in Slovakia. Its sporadic occurrences recognised to date, most probably, do not correspond to the final range of distribution of Common milkweed in Slovakia, but instead the currently existing populations represent the third stage of establishment in a staircase model of invasion. Therefore, we recommend further surveying of the structure and dynamics of $A$. syriaca populations in Slovakia, including studies on seed production, seed dispersal, soil seed bank and biological control of the species.

Acknowledgements. This work was supported by the Slovak Grant Agency for Sciences (VEGA), grant No. $1 / 1220 / 12$ and by project "Build the research centre AgroBioTech" ITMS code 26220220180.

\section{REFERENCES}

BHOWMIK, P.C. 1978. Germination, growth and development of Common Milkweed. In Canadian Journal of Plant Science, vol. 58, pp. 493-498.

BHOWMIK, P.C. - BANDEEN, J.D. 1976. Biology of Canadian weeds. 19. Asclepias syriaca L. In Canadian Journal of Plant Science, vol. 56, pp. 579-589.

CAMPBELL, T.A. 1984. Growth analysis in Common Milkweed (Asclepias syriaca). In Canadian Journal of Botany, vol. 63, pp. 2345-2349. DOI: 10.1139/b85-335. 
CSONTOS, P. - BÓZSING, E. - CSERESNYÉS, I. PENKSZA, K. 2009. Reproductive potential of the alien species Asclepias syriaca (Asclepiadaceae) in rural landscape. In Polish Journal of Ecology, vol. 57, no. 2, pp. $383-388$.

CRAMER, G.L. - BURNSIDE, O.C. 1982. Distribution and interference of Common Milkweed (Asclepias syriaca) in Nebraska. In Weed Science, vol. 30, pp. 385-388.

DECREE $173 / 2011$ of the Ministry of the Environment about invasive plant species.

GOJDIČOVÁ, E. - CVACHOVÁ, A. - KARASOVÁ, E. 2002. List of non-native, invasive and expansive vascular plant species of Slovakia. In Ochrana príro$d y$, vol. 21, pp. 59-79.

HARTZLER, R.G. - BUHLER, D.D. 2000. Occurence of Common Milkweed (Asclepias syriaca) in cropland and adjacent areas. In Crop protection, vol. 19, pp. 363-366.

LAW $543 / 2002$ on the protection of nature and land of the Slovak Republic.

MARHOLD, K. et al. 1998. Ferns and Flowering Plants. In MARHOLD, K. - HINDÁK, F. List of higher and lower plant species of Slovakia. Bratislava: Veda. 688 pp. ISBN 80-224-0526-4.

MEDVECKÁ, J. - KLIMENT, J. - MÁJEKOVÁ, J. HALADA, L. - ZALIBEROVÁ, M. - GOJDIČOVÁ, E. - FERÁKOVÁ, V. - JAROLÍMEK, I. 2012. Inventory of the alien flora of Slovakia. In Preslia, vol. 84 , pp. 257-309.

MICHAL, P. 2003. Analýza prírodného prostredia. Ipel'ská kotlina [Analysis of the natural environment.
Ipel'ská kotlina]. UMB Banská Bystrica, pp. 19-90. ISBN 80-8055-859-0.

RUŽIČKA， M. 1952. Two naturalized species from Záhorie (in Slovak). In Biologický Sbornik, Bratislava : SAV Bratislava, vol. 7, pp. 131-133.

SHANNON, T.R. - WYATT, R. 1986. Reproductive biology of Asclepias exaltata. In American Journal Botany, vol. 73, pp. 11-20.

SHMÚ, 2013. Data from the meteorological station in the village Dolné Plachtince in 2012, Slovak Hydrometeorological Institute.

VALACHOVIČ, M. 1987. On coenology of Asclepias syriaca in Záhorská nížina lowland (West Slovakia), (in Slovak). In Zprávy Československej Botanickej Společnosti, Praha, vol. 22, pp. 59-60.

VALACHOVIČ, M. 1988. Notes on the biology of the species Asclepias syriaca in the Záhorská nížina Lowland. In Zbornik z konferencie mladých vedeckých pracovnikov, Bratislava : CBEV SAV, pp. 58-63.

VALACHOVIČ, M. 1989. Reproductive biology of Asclepias syriaca populations in Záhorská nížina Lowlands. I, Notes on flower biology and fruit production. In Biológia, vol. 44, pp. 37-42.

VALACHOVIČ, M. 1991. Reproductive biology of Asclepias syriaca populations in Záhorská nížina Lowlands. II, Notes on viability, seed germination a seedling development. In Biológia, vol. 46, pp. 399-404.

Received: August 2, 2013 